\title{
The Influence of Machining Parameters on the Surface Porosity of a Closed-Cell Aluminium Foam
}

\author{
Boštjan Razboršek* - Janez Gotlih - Timi Karner - Mirko Ficko \\ University of Maribor, Faculty of Mechanical Engineering, Slovenia
}

Aluminium foam elements foamed into moulds, have a porous core, surrounded by a thin layer of non-porous outer surface. This layer affects the homogeneity and mechanical properties of the element significantly. To produce functional elements, the foams can be machined to a desired end shape. Machining deforms the surface structure, which results in a reduction of strength properties. This article describes an experimental approach to determine the effects of machining parameters on the surface porosity of closed-cell aluminium foam samples. The samples were machined by incremental forming and friction rolling with precisely defined processing parameters (deformation depth, feed rate and spindle speed). High-resolution digital photos of the treated surfaces were taken and analysed using image segmentation with a multispectral threshold algorithm. The change of surface porosity was calculated for each sample, and the influence of the selected machining parameters was determined by the use of response surface methodology. The optimal machining parameters are presented.

Keywords: aluminium foam, machining, incremental forming, friction rolling, surface porosity, integral skin

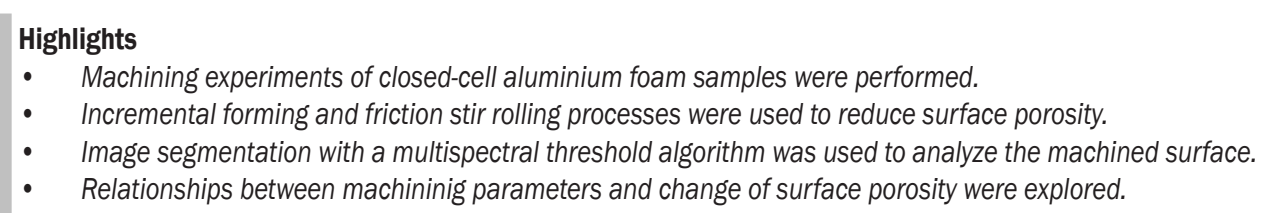

O INTRODUCTION

In recent years, interest in metal foams has increased significantly. The main reasons are new concepts in the construction of ultra-light and energy absorbing products and structures, especially in transportation and construction [1]. With their unique combination of structural properties on the one hand and basic material properties on the other hand, metal foams have great potential for future use in many applications [2].

Foamed materials retain some of the physical properties of their basic material (e.g. noncombustibility, electrical conductivity), while some physical, thermal, electrical and acoustic properties change significantly [3]. Metal foams are materials with cellular structure, consisting of hard metal and air pores, which comprise $75 \%$ to $95 \%$ of the total volume. Based on their cellular structure (morphology), they form closed-cell elements or stay as open-cell elements. Because of their typical behaviour under compressive load, and a long, nearly horizontal curve of stress - strain (stress plateau), they represent an ideal material for the absorption of impact energy [4].

Research of aluminium foams is oriented in three directions: production, processing and application. Historic production processes controlled foam density rather than the growth of cellular structures, which led to unpredictable structural and mechanical properties of the end products. Improvements in production processes made commercial use of aluminium foams much wider [5]. Today, for design purposes numerical simulations of aluminium foams are applied [6]. With further development of additive or other cost effective manufacturing techniques, cellular materials show huge potential to become important light-weight structural materials of the future [7].

Aluminium, nickel, magnesium, lead, brass, titanium, copper, steel and even golden foams are known. Among them, aluminium foams are the most researched and commercially interesting, due to their extremely low density, high transformability, low thermal conductivity and competitive production prices [8]. To further improve their mechanical properties, metal matrix syntactic foams have been developed. In these porous materials the porosity is ensured by incorporating either ceramic or metallic hollow spheres [9]. The influence of different hollow spheres and structures at different conditions and temperatures on mechanical properties was investigated by Movahedi et al. [10], Zhao et al. [11], Taherisharg et al. [12] and Linul et al. [13].

To achieve the final shape of aluminium foam products, machining is an widely used option [1]. The problem is that after machining, the outer surface becomes extremely porous, with strongly deformed cells, which changes the mechanical properties of the product. Machining of aluminium foam with a porous outer surface was studied by Hunt [14]. It 
was found that, with a special process of infiltration of a particular medium into the outer surface pores and appropriate cutting parameters, it is possible to achieve no deformation, and that surface porosity remains the same as before the treatment. For the same reason Mane [15] used ice as an infiltrant. Michailidis et al. [16] investigated milling of porous aluminium. They found that an increase of the chip thickness have a beneficial effect in avoiding burr formation and pore closures through permanent deformations of the workpiece. De Jaeger et al. [17] compared four different methods of cutting open-cell aluminium foam, namely, cutting with a circular saw, band saw, cutting with wire, and electrical discharge machining (EDM). It was observed that cutting with a circular saw and band saw resulted in significant plastic deformation of the cut surface. Cutting with saw wire and via EDM does not result in any local compression. Surface roughness of the EDM process was considerably worse than the result obtained with saw wire. Ghose et al. [18] investigated the processing of closed-cell aluminium foam by EDM. They identified various control parameters of EDM for effective machining of aluminium foam and achieving optimal surface roughness. Matz et al. [19] examined the influence of flushing on the EDM process. They found that high feed rate can be achived due to the good flushing conditions and low density of the material. Michalidis et al. [20] optimized the EDM process to eliminate surface cell damages, affecting the mechanical response under quasi-static and highvelocity impact loads. Liu et al. [21] used laser cutting process for efficiently and directly cutting of three different types and two levels of pore density of metal foams into regular shapes. The results show that metal foam with a good surface quality can be obtained without damaging the pore structure.

In general, the surface quality of metal foams is not sufficient for many constructive applications. Due to the foaming process, the surface of foams contains many cracks and oxides and is rough and wavy. Fluids or gases can penetrate into the foam along the cracks and open pores. If exposed to a corrosive environment, corrosion will not only start on the surface, but also within the foam. Furthermore, the integral skin is very thin, and cannot be machined to a decent surface finish [22]. When machining elements produced by indirect foaming in moulds, a thin layer of integral skin is removed (non-porous surface). This results in collapsing of the surface compactness and interruption of stress forces. Such products have reduced strength and they wear easily if exposed to friction, due to their porous surface and low hardness. Several methods and procedures, like thermaly sprayed coatings [22], agehardening heat treatment [23] and surface treatment by resin [24], have been developed in order to improve the quality of the outer porous surface, and, thus, wear and corrosion resistance and mechanical properties of the metal foams. Qiao et al. [25] investigated the effect of surface structure on mechanical properties of opencell aluminium foam after machining. They found that the strenght of these materials may be enhanced trought surface structural gradients. On the other hand, some forming processes have been applied to control the surface porosity of porous metals. To improve mechanical properties, for example, the surface of lotus-type porous copper has been formed by wire-brushing [26]. In this process the cell walls near the surface were plastically deformed, and a nonporous layer was fabricated at the surface with fine grains. Friction stir incremental forming process was applied on the surface of porous aluminium foam to fabricate a non-porous layer. In the process, the cell walls near the surface were plastically deformed by a rotating tool with a high rotation rate. A non-porous layer thinner than $0.4 \mathrm{~mm}$ was fabricated at the surface without internal fracture of the aluminium foam [27]. Kwon at al. [28], modified the surface region of EDM aluminium foams by the friction-surface-modifying and rolling (FSMR) process. A new surface was obtained successfully through the FSMR process, which was considerably smoother and denser than that of the unprocessed aluminium foam.

According to the literature, the quality of the aluminum foam surface depends on its treatment processes. The aim of our research work is to determine the influence of different processing parameters on its surface porosity. Two different forming processes were used, namely, friction stir incremental forming (FSIF) and friction stir rolling (FSR). Both processes are well-known in the forming of sheet metal, where plastic deformation and surface transformation occur due to a rotating tool [29]. The result of such sheet metal forming is a fine-grained surface structure of the product. The structure is formed by dynamic recrystallization at high temperatures, caused by friction [27].

\section{MATERIALS AND METHODS}

In this research work, a closed-cell aluminium foam, with the commercial name Foamtech ${ }^{\circledR}$ (supplier AlCarbon) (Fig. 1) was used for FSIF and FSR studies. The technical properties of Foamtech ${ }^{\circledR}$ are given in Table 1. 


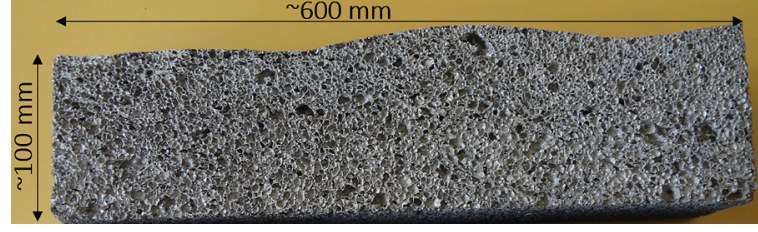

Fig. 1. Closed-cell aluminium foam - Foamtech ${ }^{\circledR}$

Table 1. Technical properties of Foamtech ${ }^{\circledR}$

\begin{tabular}{|c|c|c|c|}
\hline \multicolumn{2}{|l|}{ Classification } & Unit & Values \\
\hline \multirow{2}{*}{$\begin{array}{l}\text { Basic } \\
\text { properties }\end{array}$} & $\begin{array}{l}\text { Material composition } \\
\text { / alloy }\end{array}$ & / & $\begin{array}{c}\text { Al. }(\geq 97.5 \%) / \\
\text { AA.1070 }\end{array}$ \\
\hline & Structure & / & Closed Cell \\
\hline \multirow{7}{*}{$\begin{array}{l}\text { Physical } \\
\text { properties }\end{array}$} & Compressive strength & $\mathrm{MPa}$ & $1.0 \sim 1.8$ \\
\hline & $\begin{array}{l}\text { Flexural strength } \\
\text { (by 4-point bending) }\end{array}$ & $\mathrm{MPa}$ & $0.9 \sim 2.0$ \\
\hline & Tensile strength & $\mathrm{MPa}$ & $0.5 \sim 1.2$ \\
\hline & Shear strength & $\mathrm{MPa}$ & $0.7 \sim 1.5$ \\
\hline & Density & $\mathrm{g} / \mathrm{cm}^{3}$ & $0.15 \sim 0.3$ \\
\hline & Heat conductivity & $\mathrm{W} /(\mathrm{mK})$ & Approx. 0.1 \\
\hline & $\begin{array}{l}\text { Specific energy } \\
\text { absorption } \\
\text { (50\% deformation) }\end{array}$ & $\mathrm{MJ} / \mathrm{m}^{3}$ & $\begin{array}{c}0.61 \\
\text { (at density } 0.2 \mathrm{~g} / \mathrm{cm}^{3} \text { ) }\end{array}$ \\
\hline \multirow[t]{2}{*}{ Dimension: } & $\begin{array}{l}\text { Thickness } \\
\text { min. - max. }\end{array}$ & $\mathrm{mm}$ & $9 \sim 100$ \\
\hline & Standard panel size & $\mathrm{mm}$ & $1200(\mathrm{~L}) \times 600(\mathrm{~W})$ \\
\hline
\end{tabular}

Samples were prepared with a band saw, using a low feed rate $(\sim 0.05 \mathrm{~m} / \mathrm{min})$ and coolant, resulting in minimum deformation of the sawn surface. The dimensions of the samples were $(50 \times 40 \times 40) \mathrm{mm}$. A clamping device for the samples was designed and manufactured. The device was designed to allow rigid clamping of the samples without causing any structural deformation due to the clamping force. For forming, a carbide rod tool was used with $20 \mathrm{~mm}$ diameter and $1.5 \mathrm{~mm}$ rounding radius. The surface roughness of the tool was Ra1.6. The experimental work was carried
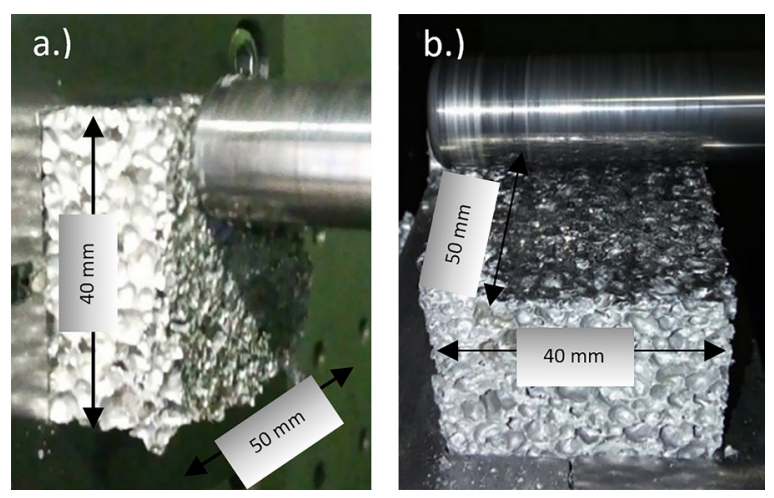

Fig. 2. a) Incremental forming, and b) friction rolling out on a 4-axis, horizontal CNC milling machine Heller BEA1. Two processing methods were used. The first method was machining with the flat part of the tool (incremental forming, FSIF) (Fig. 2a). The second method was machining with the side part of the tool (friction rolling, FSR) (Fig. 2b).

\section{EXPERIMENTAL PART}

The experiment was designed as a full factorial $3^{3}$ experiment with three factors and three levels for each factor (Table 2). Each factor was tested at each level in every possible combination. A total of 27 experiments of FSIF and 27 experiments of FSR were performed.

Table 2. Factors and levels of experiment

\begin{tabular}{lccc}
\hline \multirow{2}{*}{ Factor } & \multicolumn{3}{c}{ Level } \\
\cline { 2 - 4 } & 0 & 1 & 2 \\
\hline Spindle speed [rmp] & 16 & 2000 & 4000 \\
\hline Feed rate [mm/min] & 250 & 500 & 1000 \\
\hline Total depth of forming $[\mathrm{mm}]$ & 2 & 4 & 6 \\
\hline
\end{tabular}

The entire surface of the samples was machined in three directional passes of the tool with a depth of $1 \mathrm{~mm}$ at each pass. The resulting surface porosity was used as the response of the experiment. The surface of the samples was painted yellow, to obtain a better contrast between the non-porous and the porous parts of the surface. Ten untreated samples were also painted. The mean value of their surface porosity represented the reference surface porosity value. High-resolution images of painted surfaces were taken with a digital camera. Removing a $2.5 \mathrm{~mm}$ wide edge reduced the size of the surface to be analysed to $(45 \times 35) \mathrm{mm}$, and eliminated the influence of deformation at the edges. Image segmentation with a multispectral threshold algorithm, slicing technique, and interactive selection of the threshold with aid of an image histogram, was used to transform the images to binary form. By thresholding each channel separately and combining the results using Boolean operations, we effectively found segments of the $n$-dimensional channel space (where $n$ is the number of channels), where each image pixel was plotted using its channel values for coordinates. After thresholding and combining the red and the green channel for each pixel and excluding the pixels with a high blue value, the result was an image of yellow and black pixels. (Fig. 3a). Yellow pixels, which represent the non-porous surface, were transformed to white pixels, to create the final black and white binary image (Fig. 3b). 


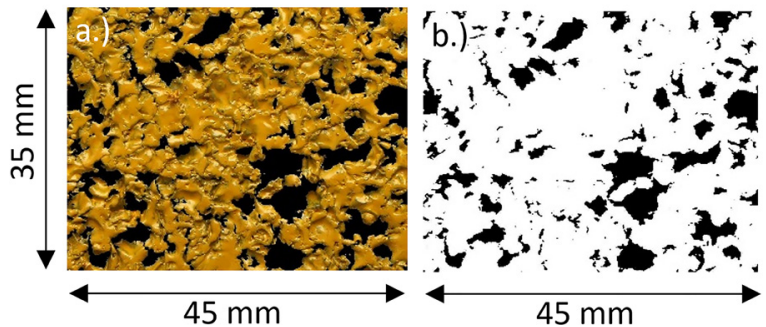

Fig. 3. a) yellow/black image, and b) binary image

The proportion of white pixels in relation to the total number of image pixels represented the proportion of the non-porous surface relative to the total area analysed.

The proportion of the non-porous surface $S_{n p}$ of a sample was evaluated (the surface coloured yellow). According to Eq. (1), the proportion of surface porosity $S_{p}$ was calculated, whereby it was presumed that value 1 represents a completely non-porous surface.

$$
S_{p, n}=1-S_{n p, n}
$$

The mean reference value of the surface porosity $S_{p, \text { mid }}$ of the ten untreated reference samples was

Table 3. Reference surface porosity

\begin{tabular}{|c|c|c|c|c|c|c|c|c|c|c|}
\hline Ref. sample & 1 & 2 & 3 & 4 & 5 & 6 & 7 & 8 & 9 & 10 \\
\hline Proportion of non-porous surface $S_{n p}[\%]$ & 52.9 & 41.9 & 48.5 & 51.1 & 45.0 & 44.3 & 40.6 & 49.3 & 43.8 & 53.6 \\
\hline Proportion of porous surface $S_{p}[\%]$ & 47.1 & 58.1 & 51.5 & 48.9 & 55.0 & 55.7 & 56.4 & 50.7 & 56.2 & 46.4 \\
\hline Mean value of porous surface $S_{p, \text { mid }}[\%]$ & \multicolumn{10}{|c|}{52.6} \\
\hline Standard deviation [\%] & \multicolumn{10}{|c|}{4.22} \\
\hline Deviation of the individual sample [\%] & -5.5 & +5.5 & -1.1 & -3.7 & +2.4 & +3.1 & +3.8 & -2.0 & +3.6 & -6.2 \\
\hline
\end{tabular}

Table 4. Design matrix and response data of FSIF and FSR experiments

\begin{tabular}{|c|c|c|c|c|c|}
\hline \multirow{2}{*}{ Sample } & \multicolumn{3}{|c|}{ Factors } & \multicolumn{2}{|c|}{ Response } \\
\hline & Processing depth, $a[\mathrm{~mm}]$ & Feed rate, $f[\mathrm{~mm} / \mathrm{min}]$ & Spindle speed, $n$ [rpm] & Change of porosity [\%] FSIF & Change of porosity [\%] FSR \\
\hline 1 & 2 & 200 & 16 & 65.5 & 54.2 \\
\hline 2 & 2 & 200 & 2000 & 53.2 & 63.4 \\
\hline 3 & 2 & 200 & 4000 & 65.2 & 48.9 \\
\hline 4 & 2 & 500 & 16 & 53.7 & 68.4 \\
\hline 5 & 2 & 500 & 2000 & 59.9 & 67.2 \\
\hline 6 & 2 & 500 & 4000 & 56.2 & 62.5 \\
\hline 7 & 2 & 1000 & 16 & 42.8 & 47.3 \\
\hline 8 & 2 & 1000 & 2000 & 59.8 & 54.9 \\
\hline 9 & 2 & 1000 & 4000 & 65.9 & 63.9 \\
\hline 10 & 4 & 200 & 16 & 83.5 & 77.2 \\
\hline 11 & 4 & 200 & 2000 & 87.5 & 83.2 \\
\hline 12 & 4 & 200 & 4000 & 8.0 & 86.4 \\
\hline 13 & 4 & 500 & 16 & 66.6 & 71.0 \\
\hline 14 & 4 & 500 & 2000 & 86.1 & 76.2 \\
\hline 15 & 4 & 500 & 4000 & 87.2 & 60.3 \\
\hline 16 & 4 & 1000 & 16 & 68.0 & 69.1 \\
\hline 17 & 4 & 1000 & 2000 & 80.4 & 71.7 \\
\hline 18 & 4 & 1000 & 4000 & 85.6 & 79.4 \\
\hline 19 & 6 & 200 & 16 & 71.0 & 79.1 \\
\hline 20 & 6 & 200 & 2000 & 90.5 & 83.6 \\
\hline 22 & 6 & 200 & 4000 & 98.3 & 94.5 \\
\hline 22 & 6 & 500 & 16 & 74.1 & 71.9 \\
\hline 23 & 6 & 500 & 2000 & 92.4 & 69.8 \\
\hline 24 & 6 & 500 & 4000 & 86.8 & 67.1 \\
\hline 25 & 6 & 1000 & 16 & 74.9 & 78.5 \\
\hline 26 & 6 & 1000 & 2000 & 73.6 & 85.8 \\
\hline 27 & 6 & 1000 & 4000 & 82.1 & 82.5 \\
\hline
\end{tabular}


calculated using Eq. (2), where $S_{p, r}$ is the surface porosity of the individual reference sample, and $k$ is the number of reference samples.

$$
S_{p, \text { mid }}=\frac{1}{k} \sum_{i=1}^{k} S_{p, r, k, i} \text {. }
$$

Change of surface porosity for each sample was calculated according to Eq. (3).

$$
\Delta S_{p}[\%]=\left(1-\frac{S_{p}}{S_{p, \text { mid }}}\right) \cdot 100 \% .
$$

\section{RESULTS AND DISCUSSION}

Table 3 shows the individual surface porosity values of 10 untreated reference samples, determined according to Eq. (1), and the average reference porosity value. The standard deviation of the surface porosity and the maximum deviation of individual samples was $4.22 \%$ and $6.2 \%$, respectively.
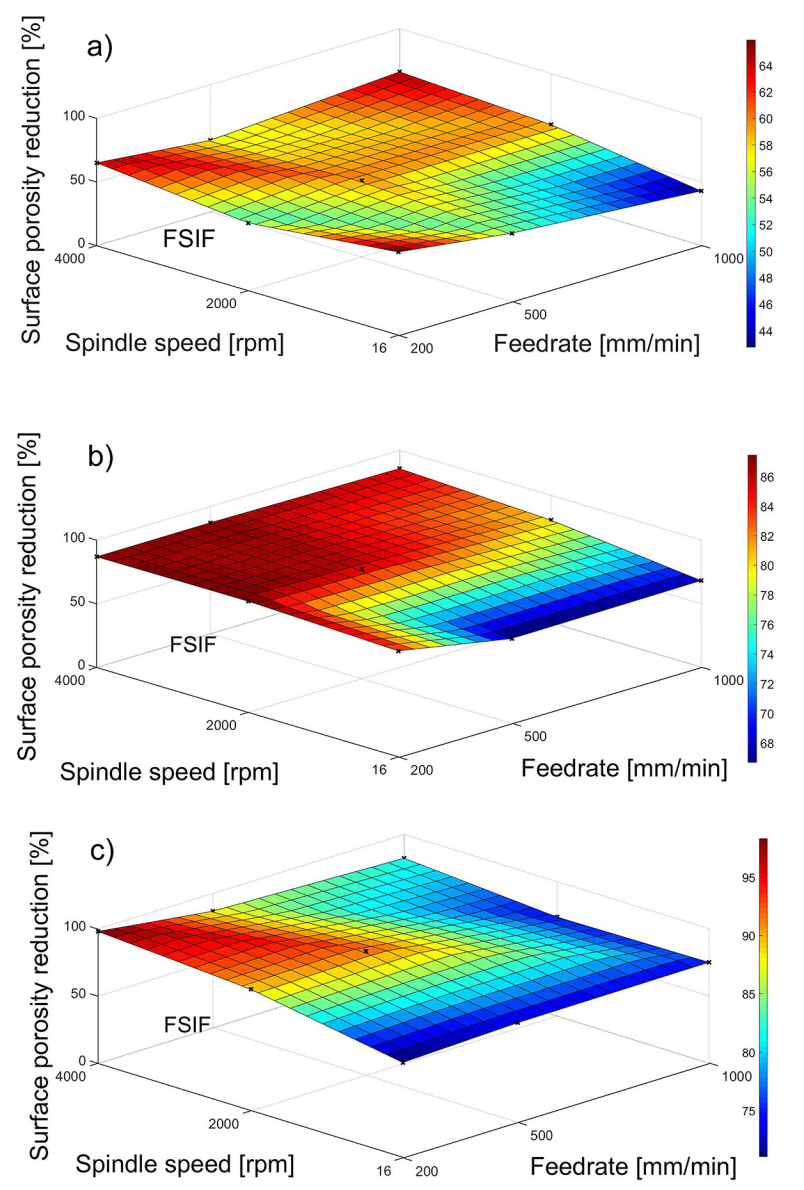

Table 4 shows the percentage change of surface porosity of the samples treated by FSIF and FSR. Results show that machining with different process parameters caused different surface porosity of the samples.

Relationships between spindle speed, feed rate, processing depth (explanatory variables) and change of surface porosity (response variable) were explored by response surface methodology. The influence of processing parameters on surface porosity is shown in the graphs below.

Fig. 4 shows the dependence of the surface porosity reduction on spindle speed and feed rate, at 2, 4 and $6 \mathrm{~mm}$ depth for FSIF and FSR. At the $2 \mathrm{~mm}$ processing depth (Fig. 4a), the change in surface porosity is relatively small (from $47 \%$ to $68 \%$ ) and distributed randomly, which is due to the size of the aluminium foam cells. At the processing depth $4 \mathrm{~mm}$ (Fig. $4 \mathrm{~b}$ ) the influence of the processing parameters on the decreasing of surface porosity is already noticeable. By increasing the spindle speed and decreasing the feed rate, up to $87 \%$ reduction of
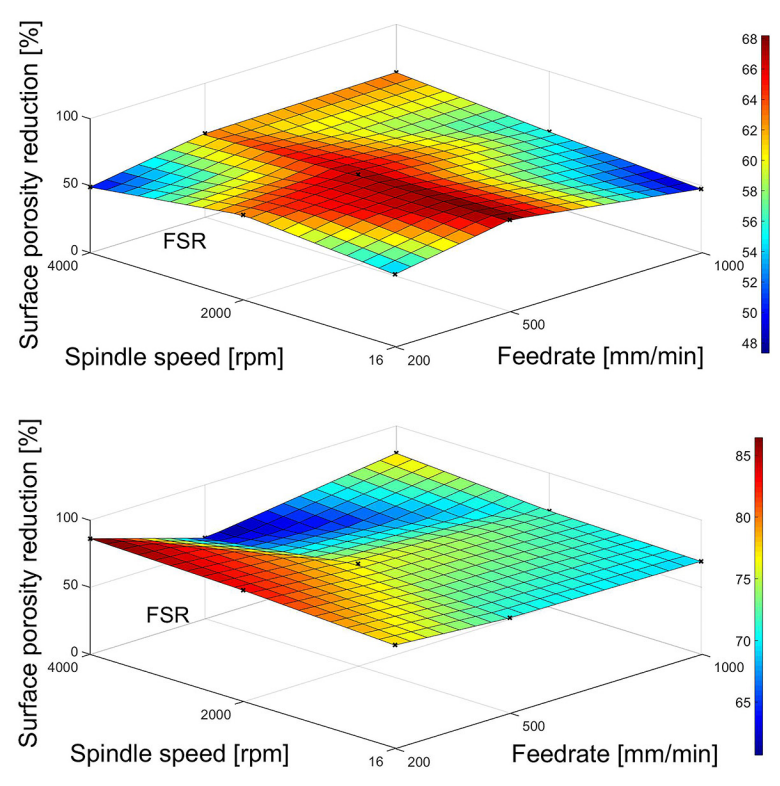

Fig. 4. Surface porosity reduction at: a) $2 \mathrm{~mm}$, b) $4 \mathrm{~mm}$, and c) $6 \mathrm{~mm}$ depth of FSIF and FSR 
surface porosity was achieved with FSIF and FSR. Surface porosity reduction is even more pronounced at $6 \mathrm{~mm}$ processing depth (Fig. $4 \mathrm{c}$ ). $98 \%$ reduction of surface porosity was achieved with incremental forming at the maximum spindle speed and the minimum feed rate. Even with FSR, the maximum surface porosity reduction was achieved with increasing of spindle speed, while the feed rate shows no significante effect.

On the Fig. 5, surface porosity reduction at the different feed rate is shown. It is clear from the graphs that, at constant feed rate of $200 \mathrm{~mm} / \mathrm{min}$ (Fig. 5a) surface porosity decreases (achieved over $90 \%$ ) with increasing spindle speed and depth of processing. This trend of surface porosity reduction applies to FSIF and FSR. At the constant feed rate $500 \mathrm{~mm} / \mathrm{min}$ (Fig. 5b) and increasing processing depth and spindle speed, higher values of surface porosity reduction were achieved with FSIF than with FSR. Maximum achived reduction of surface porosity for FSIF was 87 $\%$ while surface porosity reduction with FSR did not exceed $76 \%$. The trend of surface porosity reduction at $1000 \mathrm{~mm} / \mathrm{min}$ (Fig. 5c) is similar to the trend where a feed rate of $500 \mathrm{~mm} / \mathrm{min}$ was used. The maximum reduction of porosity at feedrate $1000 \mathrm{~mm} / \mathrm{min}$ did not exceed $85 \%$ for both processes.

Fig. 6 shows the dependence of the surface porosity reduction on processing depth and the feed rate, at a different spindle speed. It can be seen from the graphs that at spindle speed $16 \mathrm{rpm}$ (Fig. 6a) surface porosity reduction was achieved only with increasing of processing depth, while the feed rate did not have significant influence on the final results. The maximum reduction of surface porosity at $16 \mathrm{rpm}$ was $83 \%$ for FSIF and $78 \%$ for FSR. At constant spindle speed of $2000 \mathrm{rpm}$ (Fig. 6b) can be seen that processing depth has a greater influence on the reduction of surface porosity than feed rate. Reduction of surface porosity due to an increase of the processing depth from $2 \mathrm{~mm}$ to $6 \mathrm{~mm}$ is about $20 \%$, and for decreasing the feed rate from $1000 \mathrm{~mm} / \mathrm{min}$ to $200 \mathrm{~mm} / \mathrm{min}$, only $10 \%$. The largest reduction of surface porosity was $90 \%$ for FSIF and
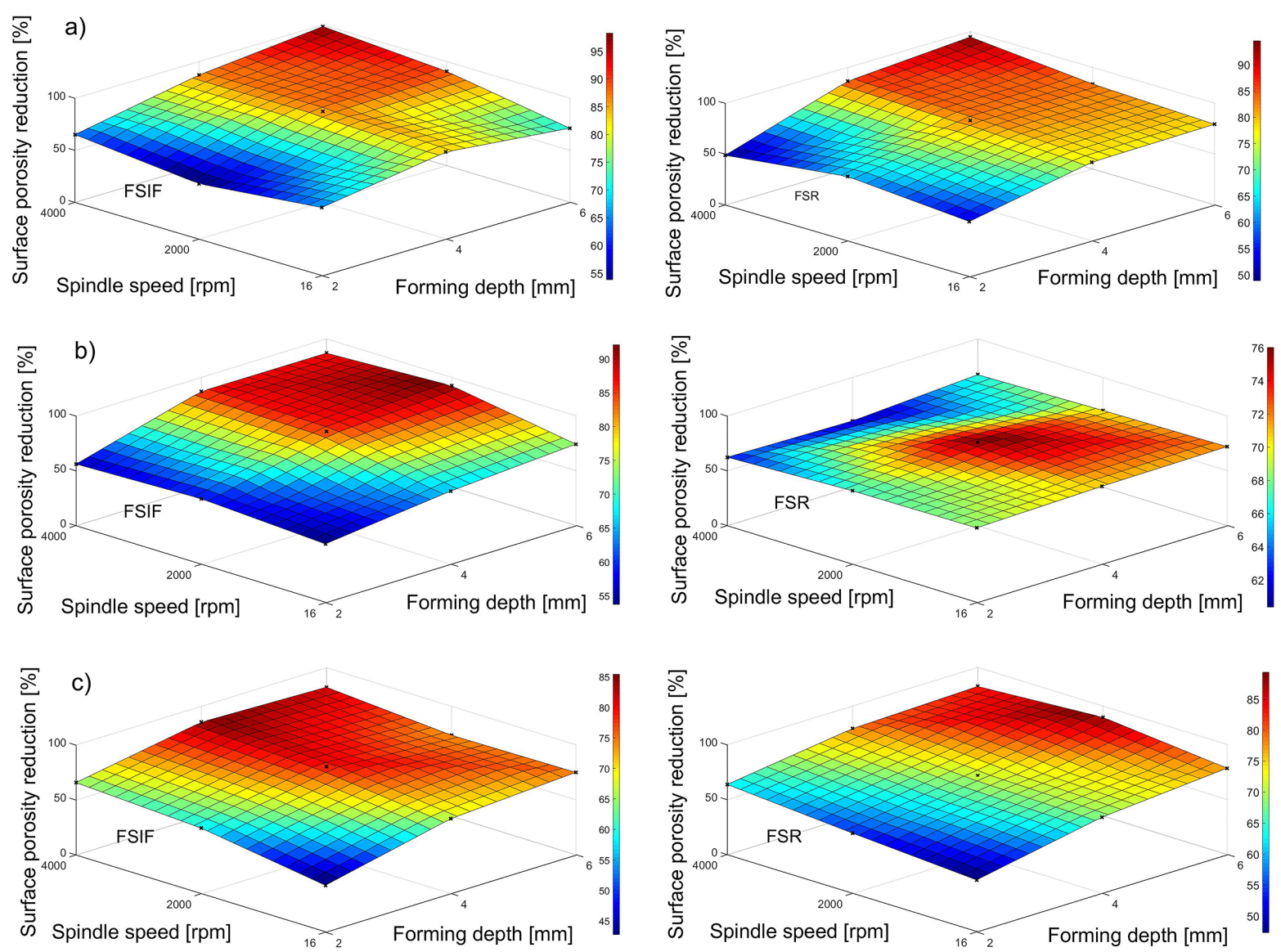

Fig. 5. Surface porosity reduction at feed rate: a) $200 \mathrm{~mm} / \mathrm{min}$, b) $500 \mathrm{~mm} / \mathrm{min}$, and c) $1000 \mathrm{~mm} / \mathrm{min}$ of FSIF and FSR 

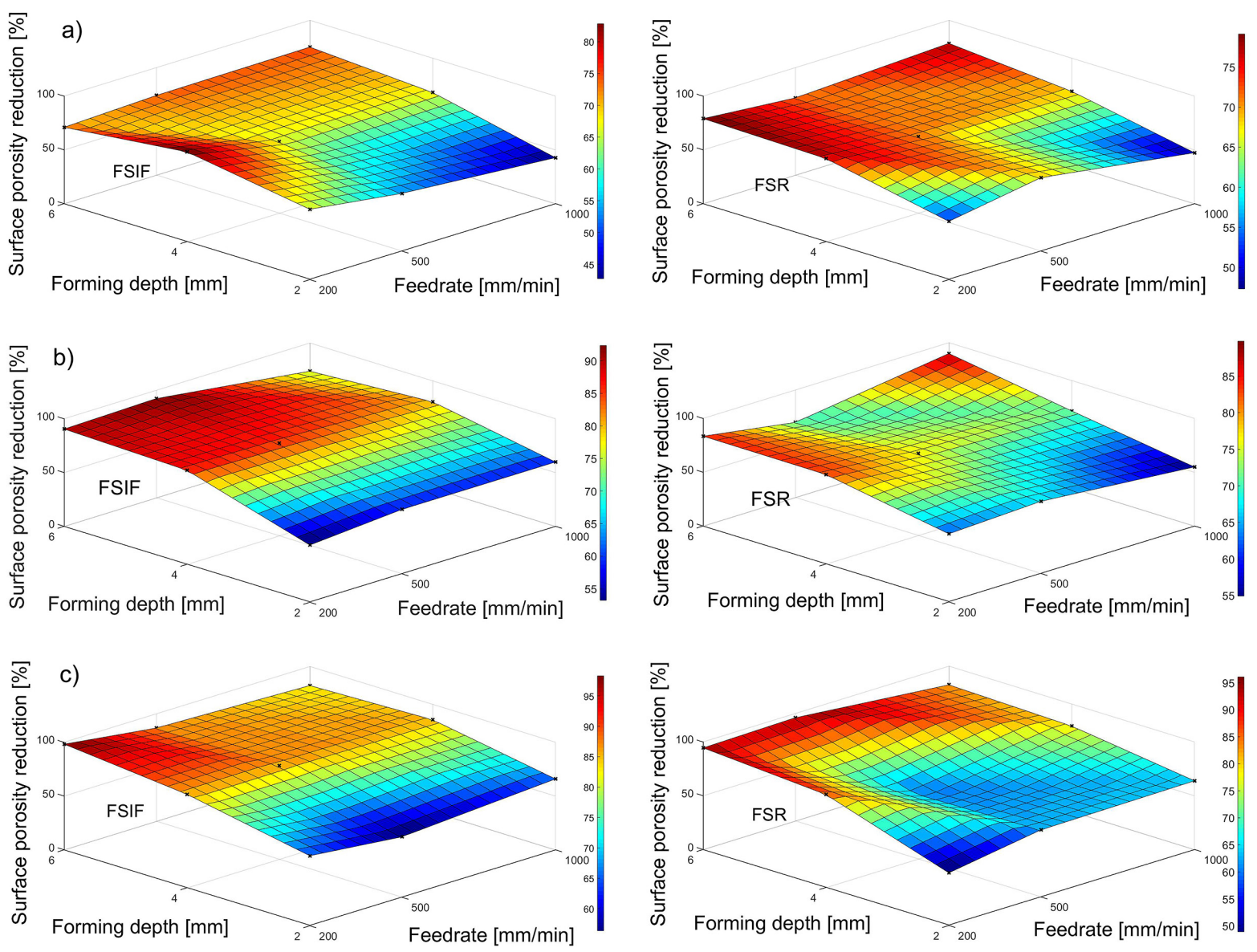

Fig. 6. Surface porosity reduction at a) $16 \mathrm{rpm}$, b) $2000 \mathrm{rpm}$, and b) $4000 \mathrm{rpm}$ (c) spindle speed of FSIF and FSR

$83 \%$ for FSR. The trend of decreasing surface porosity at constant spindle speed $4000 \mathrm{rpm}$ (Fig. 6c) was approximately the same as for processing at $2000 \mathrm{rpm}$, but the maximum achived reduction of surface porosity for FSIF was $98 \%$ and $94 \%$ for FSR.

From the test results obtained, we can conclude that changing the process parameters of incremental forming and friction rolling influences surface porosity significantly. Over $90 \%$ reduction of surface porosity was achieved for both processes. The highest reduction of surface porosity, $98.3 \%$, was achieved by FSIF at spindle speed $4000 \mathrm{rpm}$, feed rate 200 $\mathrm{mm} / \mathrm{min}$ and processing depth $6 \mathrm{~mm}$. With FSR, the highest value achieved was $96.1 \%$ at spindle speed $4000 \mathrm{rpm}$, feed rate $500 \mathrm{~mm} / \mathrm{min}$ and processing depth $6 \mathrm{~mm}$. Processing depth, followed by spindle speed, have the greatest impact on porosity reduction. Reducing of feed rate has a lower impact on surface porosity and also increases processing time, which is not reasonable. To reduce porosity, it is reasonable to increase spindle speed, since the increase of the processing depth is limited by the shape of the work piece and processing time. It is also evident from the results that an average $5 \%$ to $10 \%$ higher decrease of surface porosity was achieved in incremental forming rather than frictional rolling. Altough the FSIF and FSR processes of aluminium foam has been studied previously [21] and [28], so far this is the first report where the influence of different machining parameters on surface porosity reduction was investigated. When compared to published papers, in this study different strategies of machining were used and surface porosity analysis were carried out, using image segmentation with multispectral threshold algorithm.

\section{CONCLUSIONS}

We found that forming aluminium foams with incremental forming or friction rolling enables the reduction of surface porosity of aluminium foam elements previously processed with cutting (sawing, milling, turning). A non-porous outer surface 
(integral skin) that improves mechanical properties (e.g. strength) of the finished elements was formed using different machining parameters. By forming the material, the stress field (force lines) becomes smooth and continuous, which reduces the notch effect and raises compressive strength. Despite the high deformation depth, deformation of the processed elements remains in the local area, which is due to the cellular structure and good transformability of aluminium foams. Compact aluminium foam elements can be produced with combinations of cutting operations (milling, turning) and forming operations (incremental forming, friction rolling). Both operations can be carried out on the same machine, which lowers costs substantially. In comparison with small batch production of elements foamed into moulds, the incremental forming or friction rolling methods are cheaper, because there are no costs of mould making, and semi-finished products can be used, such as blocks, bars and sheets.

\section{ACKNOWLEDGEMENTS}

This work was supported financially by the Slovenian Research Agency (ARRS), Programme P2-0157.

\section{REFERENCES}

[1] Ashby, M.F., Evans, A., Fleck, N.A., Gibson, L.J., Hutchinson, J.W., Wadley, H.N.G. (2000). Metal Foams: A Design Guide. Butterworth-Heinemann, Oxford, DOl:10.1016/S02613069(01)00049-8.

[2] Banhart, J. (2001). Manufacture, characterisation and application of cellular metals and metal foams. Progress in Materials Science, vol. 46, no. 6, p. 559-632, Dol:10.1016/ S0079-6425(00)00002-5.

[3] Lefebvre, L.P., Banhart, J., Dunand, D.C. (2008). Porous metals and metallic foams: current status and recent developments. Advanced Engineering Materials, vol. 10, no. 9, p. 775-787, DOI:10.1002/adem.200800241.

[4] Duarte, I., Vesenjak, M., Krstulović-Opara, L. (2014). Variation of quasi-static and dynamic compressive properties in a single aluminium foam block. Materials Science and Engineering: $A$, vol. 616, p. 171-182, D0l:10.1016/j.msea.2014.08.002.

[5] Duarte, I., Oliveir, M. (2012). Aluminium alloy foams: Production and properties. Powder Metallurgy, Kondoh, K. (ed.). Intechopen, London, p. 47-72, D0I:10.5772/34433.

[6] Mankovits, T., Varga, T. A., Manó, S., Kocsis, I. (2018). Compressive response determination of closed-cell aluminium foam and linear-elastic finite element simulation of MCTbased directly reconstructed geometrical models. Strojniški vestnik - Journal of Mechanical Engineering, vol. 64, no. 2, p. 105-113, Dol:10.5545/sv-jme.2017.5048.

[7] Nečemer, B., Vesenjak, M., Glodež, S. (2019). Fatigue of cellular structures - a review. Strojniški vestnik - Journal of Mechanical Engineering, vol. 65, no. 9, p. 525-536, DOl:10.5545/sv-jme.2019.6070.

[8] Banhart, J. (2000). Manufacturing Routes for Very Low Specific. Jom 52 (December), p. 22-27.

[9] Orbulov, I.N. (2012). Compressive properties of aluminium matrix syntactic foams. Materials Science and Engineering: $A$, vol. 555, p. 52-56, D0l:10.1016/j.msea.2012.06.032.

[10] Movahedi, N., Taherishargh, M., Belova, I.V., Murch, G.E., Fiedler, T. (2018). Mechanical and microstructural characterization of an AZ91-activated carbon syntactic foam. Materials, vol. 12, vol. 1, p- 3, Dol:10.3390/ma12010003.

[11] Zhao, Y.Y., Tao, X.F. (2009). Behaviour of metal matrix syntactic foams in compression. Materials Science \& Technology Conference and Exhibition, Proceedings, p. 1785-1795.

[12] Taherishargh, M., Linul, E., Broxtermann, S., Fiedler, T. (2018). The mechanical properties of expanded perlite-aluminium syntactic foam at elevated temperatures. Journal of Alloys and Compounds, vol. 737, p. 590-596, D0l:10.1016/j. jallcom.2017.12.083.

[13] Linul, E., Marsavina, L., Kováčik, J. (2017). Collapse mechanisms of metal foam matrix composites under static and dynamic loading conditions. Materials Science and Engineering: A, vol. 690, p. 214-224, D0l:10.1016/j. msea.2017.03.009.

[14] Hunt, C.V. (2009). A Method to Reduce Smearing in the Milling of Metal Foams. PhD thesis, lowa State University, Ames, DOI:10.31274/etd-180810-591.

[15] Mane, V.V. (2016). An Effective Method to Reduce Smearing in Machining of Metallic Foams Using Ice as an Infiltrant. $\mathrm{PhD}$ thesis, lowa State University, Ames, Dol:10.31274/etd180810-4657.

[16] Michailidis, N., Kombogiannis, S., Charalampous, P., Maliaris, G., Stergioudi, F. (2017). Computational-experimental investigation of milling porous aluminium. CIRP Annals, vol. 66, no 1, p. 121-124, D0l:10.1016/j.cirp.2017.04.022.

[17] De Jaeger, P., T'Joen, C., Huisseune, H., Ameel, B., De Schampheleire, S., De Paepe, M. (2012). Assessing the influence of four bonding methods on the thermal contact resistance of open-cell aluminum foam. International Journal of Heat and Mass Transfer, vol. 55, no. 21-22, p. 6200-6210, DOI:10.1016/j.jijheatmasstransfer.2012.06.043.

[18] Ghose, J., Sharma, V., Kumar, N., Krishnamurthy, A., Kumar, S., Botak, Z. (2011). Taguchi-fuzzy based mapping of EDMmachinability of aluminium foam. Tehnički Vjesnik - Techinical Gazette, vol. 18, no. 4, p. 595-600.

[19] Matz, A.M., Kammerer, D., Jost, N., Oßwald, K. (2016). Machining of metal foams with varying mesostructure using wire EDM. Procedia CIRP, vol. 42, p. 263-267, D0l:10.1016/j. procir.2016.02.283.

[20] Michailidis, N., Klink, A., Smyrnaios, E., Olivier, M., Baklatzoglou, N., Welschof, L., Stergioudi, F. (2018). Surface structure, pore characteristics and mechanical response of aluminum foam processed by Wire-EDM and milling. MATEC Web of Conferences, vol. 188, art. no. 03012, D0l:10.1051/ matecconf/201818803012.

[21] Liu, Y., Zhou, W., Chu, X., Liu, S., Hui, K.S. (2018). Feasibility investigation of direct laser cutting process of metal foam with high pore density. The International Journal of 
Advanced Manufacturing Technology, vol. 96, p. 2803-2814, DOl:10.1007/s00170-018-1796-1.

[22] Maurer, M., Zhao, L., Lugscheider, E. (2002). Surface refinement of metal foams. Advanced Engineering Materials, vol. 4, no. 10, p. 791-797, D0l:10.1002/15272648(20021014)4:10<791::AID-ADEM791>3.0.C0;2-Q.

[23] Banhart, J., Baumeister, J. (1998). Deformation characteristics of metal foams. Journal of Materials Science, vol. 33, p. 14311440, DOI:10.1023/A:1004383222228.

[24] Kitazono, K., Suzuki, R., Inui, Y. (2009). Novel strengthening method of closed-cell aluminum foams through surface treatment by resin. Journal of Materials Processing Technology, vol. 209, no. 7, p. 3550-3554, D0l:10.1016/j. jmatprotec.2008.08.013.

[25] Qiao, H., Murthy, T.G., Saldana, C. (2019). Structure and deformation of gradient metal foams produced by machining. ASME Journal of Manufacturing Science and Engineering, vol. 141, no. 7, art. 171009, Dol:10.1115/1.4043768.
[26] Lobos, J., Suzuki, S., Nakajima, H., Ji, Y.S., Fujii, H., Terada, D., Tsuji, N. (2009). Structural change and improvement of the mechanical properties of a lotus-type porous copper by wirebrushing. Journal of Physics: Conference Series, vol. 165, no. 1, art. 012070, D0I:10.1088/1742-6596/165/1/012070.

[27] Matsumoto, R., Tsuruoka, H., Otsu, M., Utsunomiya, H. (2015). Fabrication of skin layer on aluminum foam surface by friction stir incremental forming and its mechanical properties. Journal of Materials Processing Technology, vol. 218, p. 2331, D0I:10.1016/j.jmatprotec.2014.11.030.

[28] Kwon, Y.-J., Shigematsu, I., Saito, N. (2009). Development of new production technology for metallic foam core sandwich panel using friction phenomena. Materials Transactions, vol. 50, no. 4, p. 879-884, DOl:10.2320/matertrans.MER2008321.

[29] Petek, A., Podgornik, B., Kuzman, K., Čekada, M., Waldhauser, W., Vižintin, J. (2008). The analysis of complex tribological system of single point incremental sheet metal forming - SPIF. Strojniski vestnik - Journal of Mechanical Engineering, vol. 54, no. 4, p. 266-273. 